\title{
A crise hídrica na região metropolitana de São Paulo (2014-2015)
}

\section{Vanderli Custódio \\ IEB-USP}

p. $445-463$

\section{revista}

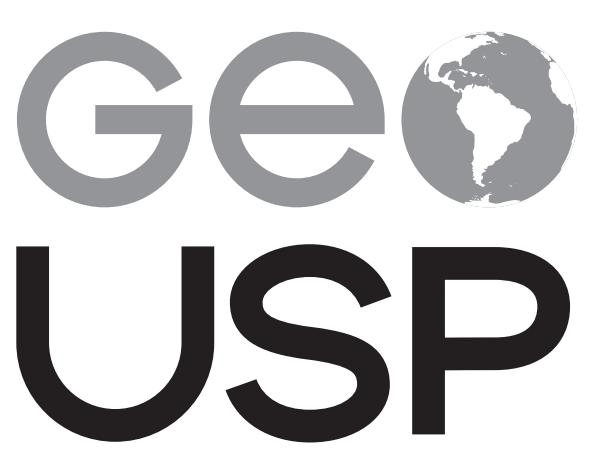

espaço e tempo

Volume $19 \cdot n^{\circ} 3(2015)$

Como citar este artigo:

CUSTÓDIO, V. A crise hídrica na Região Metropolitana de São Paulo (2014-2015). Geousp - Espaço e Tempo (Online), v. 19, n. 3, p. 445-463, mês. 2016. ISSN 21790892.

Disponível em: URL: http://www.revistas.usp.br/ geousp/article/view/102136. DOI: http://dx.doi. org/10.11606/issn.2179-0892.geousp.2015.102136.

\section{(c) $(1) \Theta$}

Este artigo está licenciado sob a Creative Commons Attribution 4.0 License. 


\title{
A crise hídrica na região metropolitana de São Paulo (2014-2015)
}

\section{Resumo}

O objetivo deste artigo é caracterizar e situar a crise hídrica na Região Metropolitana de São Paulo entre os anos 2014-2015 num contexto temporal mais amplo. Com apoio bibliográfico, procura mostrar que essa não é uma crise nova, mas uma nova fase de uma crise secular, potencializada pela frágil gestão e planejamento no abastecimento de água para o estado de São Paulo por parte do poder público, bem como que as medidas estruturais (obras) e não estruturais (programas, legislação etc.) têm histórico caráter emergencial.

Palavras-chave: Abastecimento. Água. Crise hídrica. Região Metropolitana de São Paulo. Sabesp.

\section{The water crisis in the São Paulo metropolitan region (2014-2015)}

\begin{abstract}
This article about the water crisis in the São Paulo metropolitan region between the years 2014-2015, aims to characterize it and place it in a broader temporal context. With bibliographic support attempts to show that this is not a new crisis but it's just a new phase of a secular crisis by the weak management and water supply planning for Sao Paulo by the public authorities, as well as highlight structural measures (works) and structural (programs, legislation etc.) possess emergency character history.
\end{abstract}

Keywords: Water supply. Water crisis. The metropolitan region of São Paulo. Sabesp.

\section{Introdução}

No início de 2014, por volta do mês de março, a falta de água para abastecimento doméstico na Região Metropolitana de São Paulo (RMSP) alcançou características de indício de crise. O maior sistema fornecedor para a metrópole, o Cantareira, que produz $33 \mathrm{~m} 2 / \mathrm{s}$, estava insuficiente, tanto que a Agência Nacional de Águas (ANA) determinou que fosse reduzida a adução do referido sistema com risco de entrar em colapso. $O$ fato é que o abastecimento para cerca de metade dos 19 milhões de habitantes da RMSP ficou comprometido. 
A crise ganhou os meios de comunicação e passou a ser noticiada diariamente. Sobre ela se manifestaram ambientalistas, opositores do partido político (PSDB) que perdura há mais de 20 anos no estado de São Paulo, organizações não governamentais (ONG), Ministérios Públicos estadual e federal, acadêmicos, engenheiros e povo na rua. Várias facetas foram exploradas. Afinal, esta é a primeira crise do tipo pela qual passa São Paulo? Se sim, o inesperado, como o alegado fator climático teria um peso significativo? Caso contrário, o que deixamos de aprender com as crises precedentes?

\section{O Sistema Cantareira}

A adução das águas da Serra da Cantareira, a norte da cidade de São Paulo, tem início em 1875 com a criação da Companhia Cantareira de Águas e Esgotos, a primeira empresa a fornecer água para a cidade. Com problemas financeiros e operacionais, a Companhia foi encampada pelo Estado em 1893, com a criação da Repartição de Águas e Esgotos (RAE). O sistema foi sucessivamente ampliado e atuou até a década de 1970 quando foi acrescido da adução do rio Juqueri, dando origem ao atual e grandioso Sistema Cantareira.

Trata-se da área de 12 municípios (Paschoalotti; Martini Neto, [s.d.]), quatro deles em Minas Gerais, de cinco reservatórios de regularização, Jaguari e Jacareí, interligados, Cachoeira, Atibainha e Juqueri (ou Paiva Castro); uma estação elevatória (Santa Inês); um reservatório (Águas Claras) de manutenção de águas, sete túneis e uma grande Estação de Tratamento de Águas, a ETA Guaraú (Figura 1). As águas são provenientes, em boa parte, das bacias dos rios Piracicaba, Capivari e Jundiaí. A chamada bacia PCJ.

\section{Figura 1 - Sistema Cantareira}

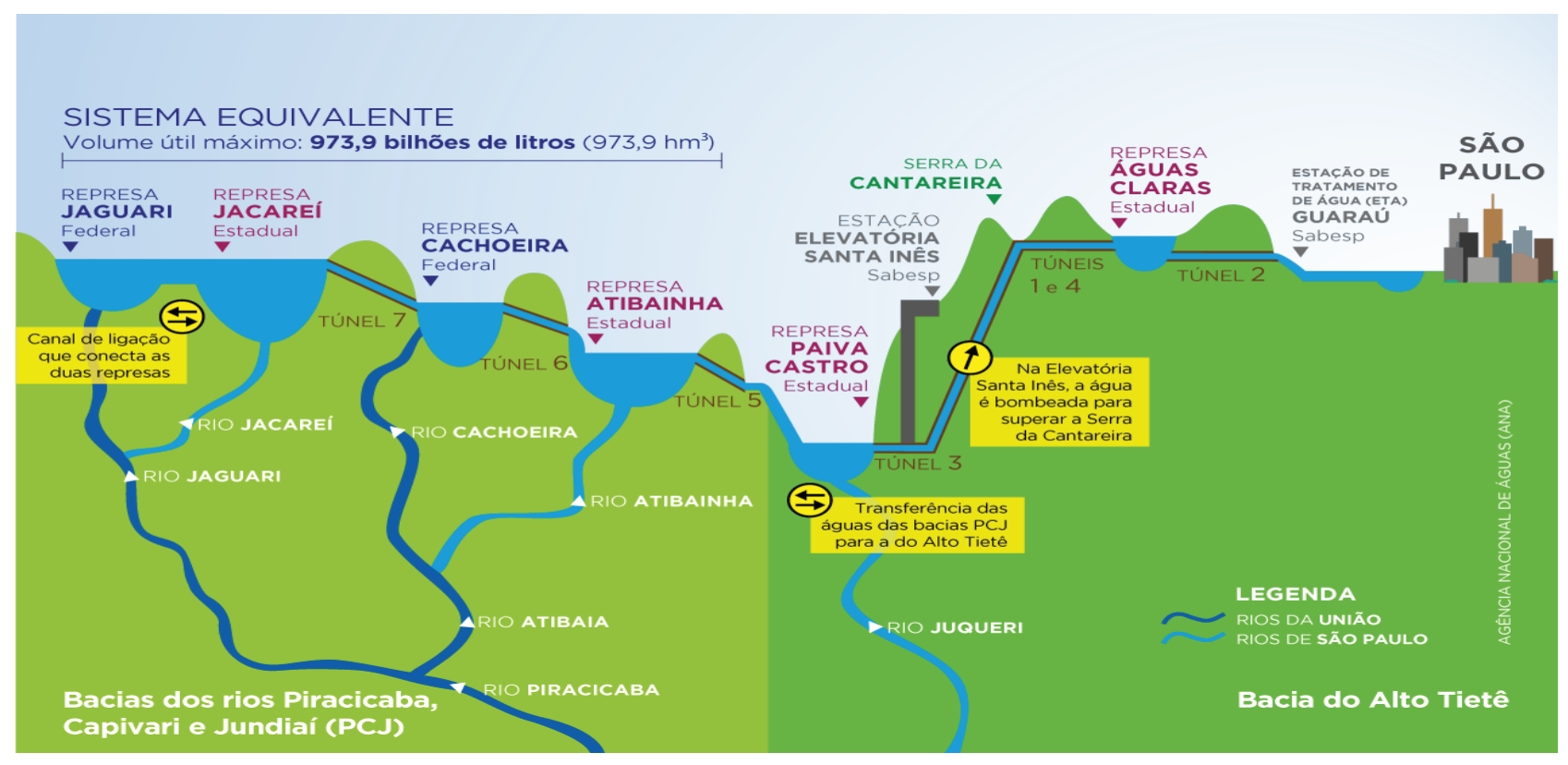

fonte: ANA (2015). 
Com o intuito de regularizar a situação do uso das águas das bacias vizinhas, em agosto de 2004 foi firmado um acordo (São Paulo, 2004), por dez anos, entre a Agência Nacional de Águas (ANA), o Departamento de Águas e Energia Elétrica do Estado de São Paulo (Daee) e os comitês das bacias respectivas. Uma outorga que autorizou serem utilizados no máximo $31 \mathrm{~m}^{3} / \mathrm{s}$ para abastecer a RMSP e $5 \mathrm{~m}^{3} / \mathrm{s}$ para as bacias do PCJ. Segundo o acordo, foi criado um Banco de Águas que:

[...] permite o armazenamento do volume não utilizado no período das chuvas para uso no período de estiagem, funcionando como uma poupança para as regiões utilizarem em períodos em que a falta de chuva exige maior atenção. Para monitorar o banco de águas os Comitês PCJ criaram uma Câmara Técnica de Monitoramento Hidrológico, que informa à ANA e ao Daee mês a mês, os volumes necessários para suprir a demanda de água na região à jusante do sistema. E, os órgãos gestores passaram a emitir, desde agosto de 2004, um comunicado conjunto informando à Sabesp e aos Comitês PCJ o saldo para o mês subsequente, obtido a partir da contabilização dos volumes não utilizados a que cada região tem direito, para posterior compensação (Paschoalotti; Martini Neto, [s.d.]).

O objetivo do Comitê PCJ é, na negociação da nova outorga que foi adiada para outubro de 2015, que se consiga autorização para utilizar $10 \mathrm{~m}^{3} / \mathrm{s}$, ao invés dos atuais $5 \mathrm{~m}^{3} / \mathrm{s}$.

Pode se perceber que há um conflito de usos entre a bacia do Alto Tietê e a bacia do PCJ. Por isso, parte do acordo é também a redução gradativa da dependência das águas do Sistema Cantareira para o abastecimento da RMSP. O que deixou de ser realizado.

Um estrangeiro perguntaria: qual é a relação existente entre a RMSP, a bacia do Alto Tietê, e quais são os demais sistemas produtores de água para a Região?

\section{A RMSP, a bacia do Alto Tietê e os seus sistemas produtores de água}

A RMSP (Figura 2) é composta por 39 municípios, 19,7 milhões de habitantes (Brasil, 2010), com área total de $8.051 \mathrm{~km}^{2}$ e 2.209 km² de áreas urbanizadas (a Grande São Paulo). Concentra 18,9\% do PIB brasileiro (IBGE, 2010), mais de 47 mil indústrias e 125 estabelecimentos comerciais. 
Figura 2 - RMSP: localização e divisão política

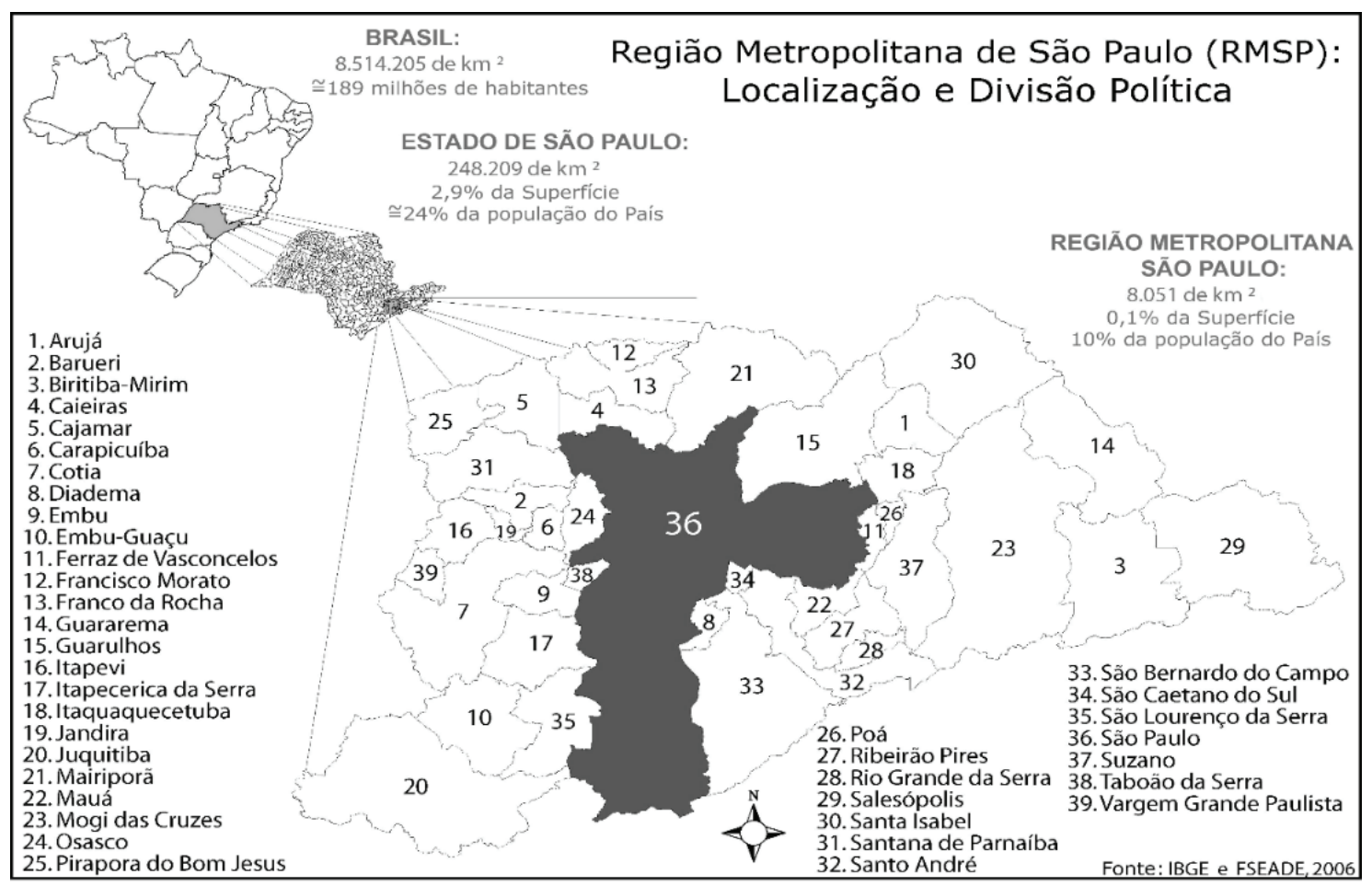

fonte: IBGE e Seade (2006). elaboração: Mateus Sampaio, 2008. reelaboração: Denis Cossia, 2010.

Cerca de 70\% da área da RMSP estão na bacia do Alto Tietê (Figura 3). Assim, a "César o que é de César", ou seja, a Região deveria usar apenas seus mananciais para abastecer seus usuários, e não reverter águas de bacias vizinhas, princípio que era um mero indicativo na época da construção do Sistema Cantareira, mas que hoje é pauta dos comitês de bacia.

\section{Figura 3 - RMSP e bacia do Alto Tietê}

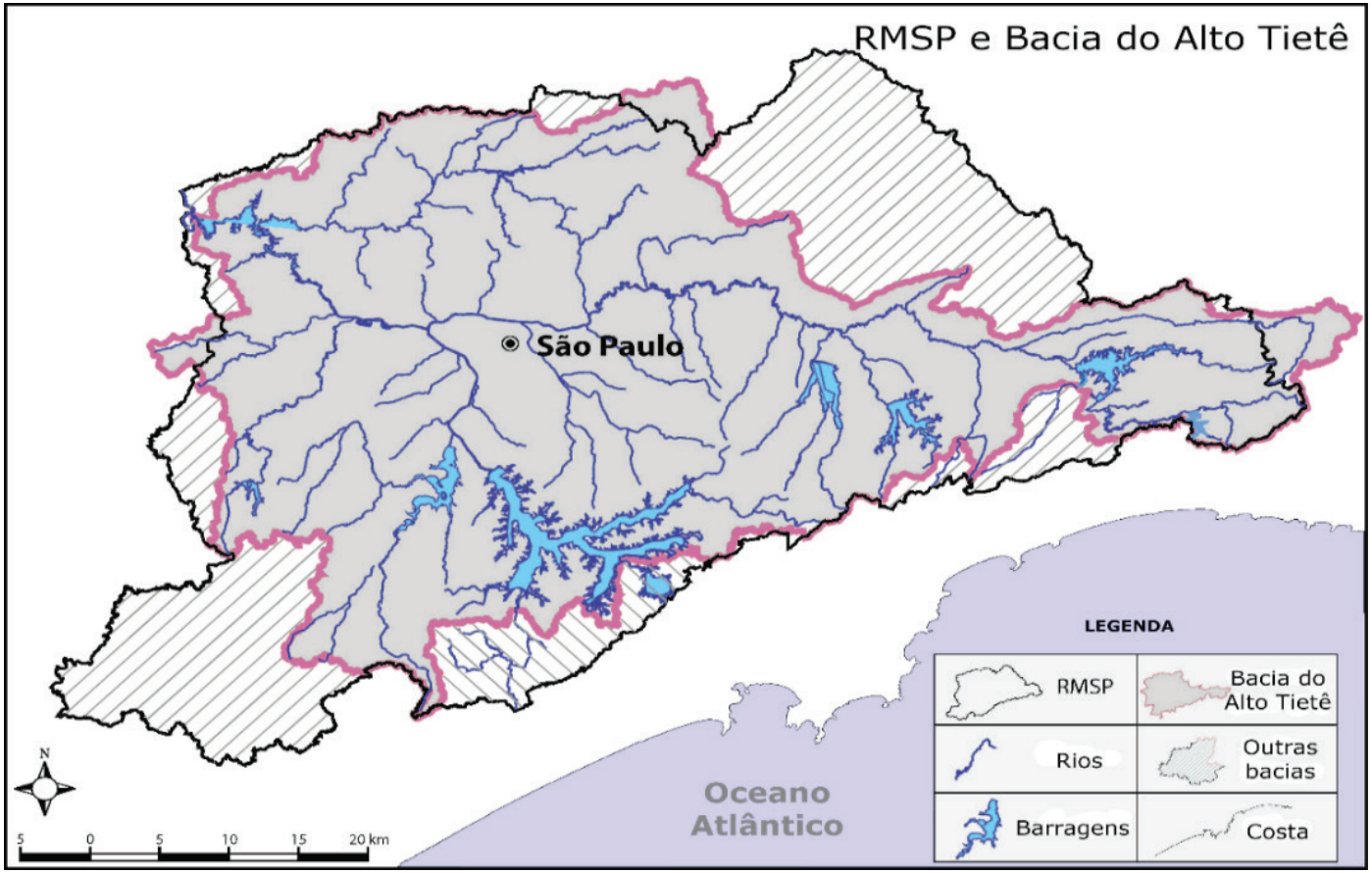

elaboração: Mateus Sampaio, 2008. reelaboração: Denis Cossia, 2010. 
A bacia do Alto Tietê, por sua vez, possui $5.868 \mathrm{~m}^{2}$, e é formada pelo rio homônimo, que nasce no município de Salesópolis, a leste na RMSP, e corre no sentido oeste até a Barragem de Rasgão, a jusante da capital. Dela fazem parte rios importantes como o Pinheiros, Tamanduateí, Aricanduva, Juqueri e centenas de outros cursos menores, além dos reservatórios Billings, Biritiba-Mirim, Guarapiranga, Jundiaí, Paiva Castro, Paraitinga, Pedro Beicht, Pirapora, Ponte Nova, Ribeirão do Campo e Taiaçupeba. Devido a sua complexidade, a bacia foi dividida em seis sub-regiões/comitês (Figura 4). Tal divisão e limites estão no contexto da criação das vinte e duas unidades de gerenciamento dos recursos hídricos do estado de São Paulo, as UGRH.

\section{Figura 4 - Sub-regiões da bacia do Alto Tietê}

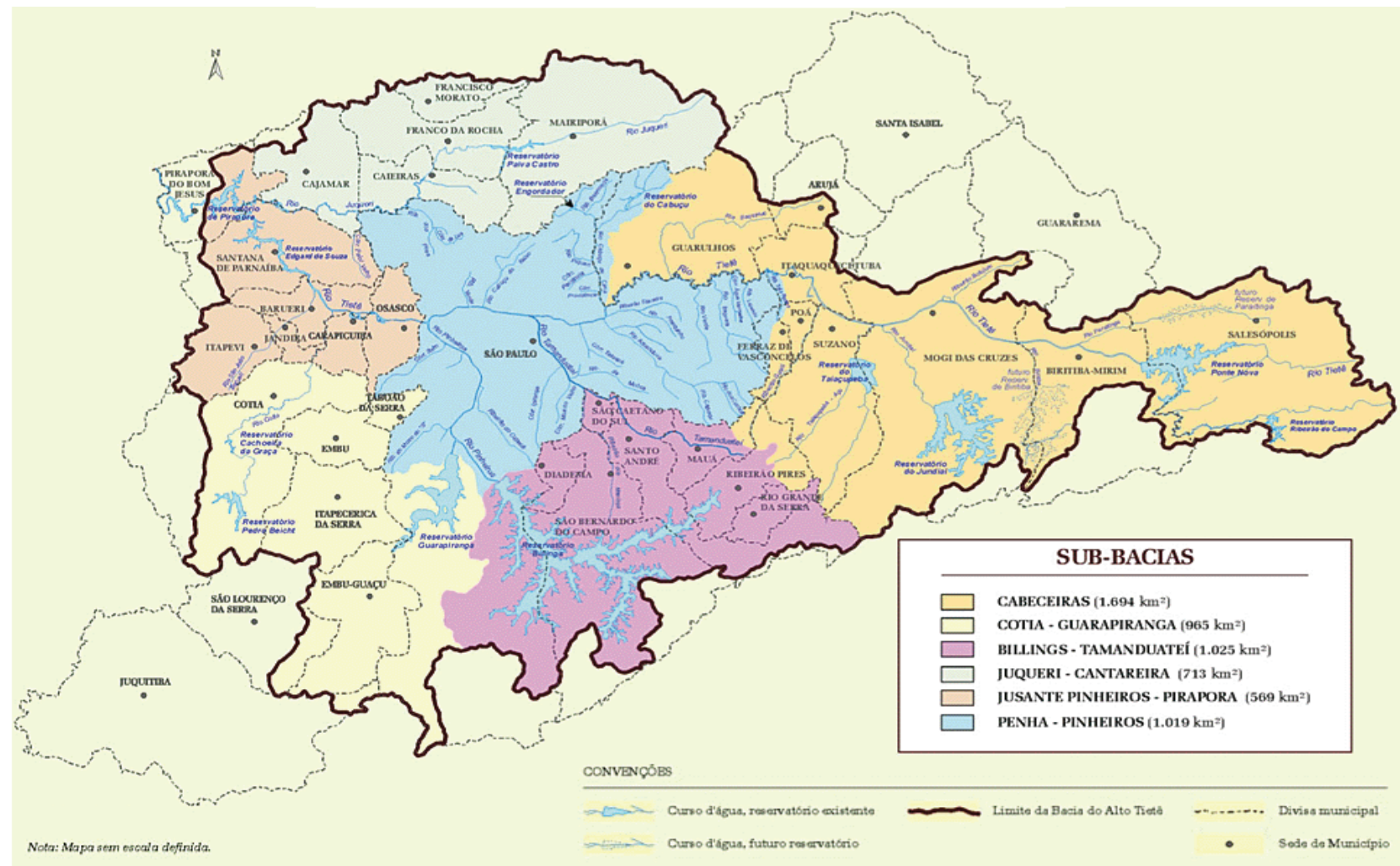

fonte: Daee (2002).

Os sistemas produtores de água da bacia do Alto Tietê (Figura 5), em 2015, são o Cantareira $\left(33 \mathrm{~m}^{3} / \mathrm{s}\right)$, sendo $31 \mathrm{~m}^{3} / \mathrm{s}$ revertidos da bacia do PCJ; o Alto Tietê $\left(15 \mathrm{~m}^{3} / \mathrm{s}\right)$; o Rio Claro $\left(4 \mathrm{~m}^{3} / \mathrm{s}\right)$ sendo 0,5 revertido do rio Guaratuba, da vertente marítima; o Sistema Rio Grande (5 $\left.\mathrm{m}^{3} / \mathrm{s}\right)$; o Guarapiranga $\left(15 \mathrm{~m}^{3} / \mathrm{s}\right)$, sendo $1 \mathrm{~m}^{3} / \mathrm{s}$ revertido do rio Capivari, da vertente oceânica; o Alto Cotia $\left(1,2 \mathrm{~m}^{3} / \mathrm{s}\right) ;$ o Baixo Cotia $\left(0,9 \mathrm{~m}^{3} / \mathrm{s}\right)$ e o Ribeirão da Estiva $\left(0,1 \mathrm{~m}^{3} / \mathrm{s}\right)$. Num total de $74,2 \mathrm{~m}^{3} / \mathrm{s}$, fornecidos pela Companhia de Saneamento Básico do Estado de São Paulo (Sabesp), criada em 1973.

Quando se pensa que o rio Tietê, no trecho em que atravessa a Grande São Paulo, possuindo uma vazão de $82 \mathrm{~m}^{3} / \mathrm{s}$, é que temos a noção de quanta água há na bacia do Alto Tietê, impossibilitada, pela poluição severa, de uso para o abastecimento doméstico e demais usos possíveis, como recreação, lazer, piscicultura etc. É o que denominamos de escassez relativa de água. Ela existe em quantidade, mas com qualidade imprópria para determinados fins. 
A localização dos sistemas nos possibilita compreender as medidas de socorro ao Sistema Cantareira que estão sendo preconizadas: (i) interligação do Sistema Rio Grande com o Sistema Alto Tietê; (ii) transposição de águas da bacia do rio Paraiba do Sul (nordeste da bacia do Alto Tietê) para o Sistema Alto Tietê; (iii) construção de um novo sistema, o São Lourenço, com águas provenientes da bacia do Ribeira do Iguape/Litoral Sul, a sudoeste da bacia do Alto Tietê.

\section{Figura 5 - Sistemas produtores de água da bacia do Alto Tietê}

\section{Os sistemas produtores de água da SABESP}

\section{- $1.500 \mathrm{~km}$ de adutoras;}

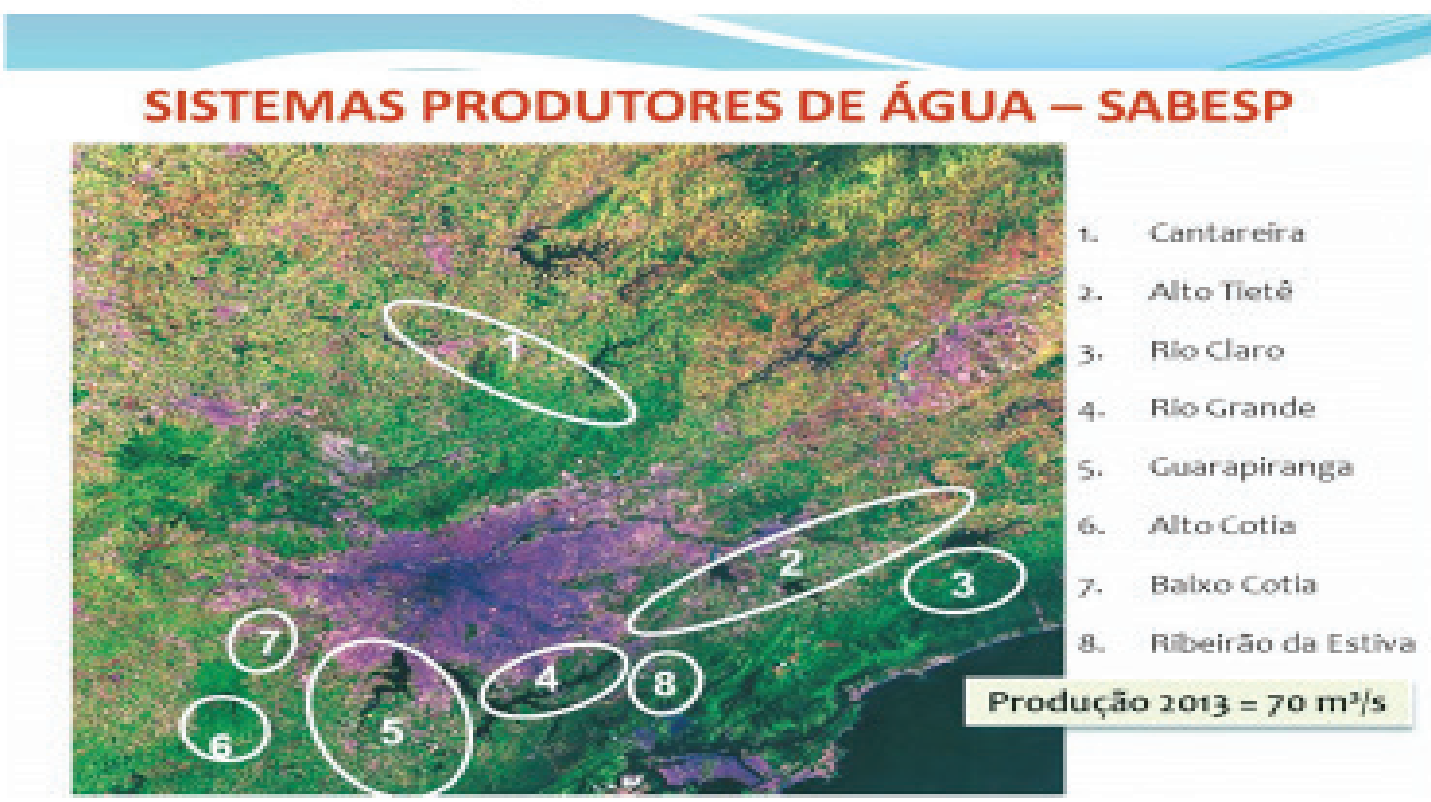

fonte: Liderança [...] (2014).

Todas soluções polêmicas, visto que predomina o uso de recursos de bacias vizinhas, causa de conflitos entre os governos estaduais de São Paulo e do Rio de Janeiro; entre comitês de bacia do Alto Tietê e Ribeira do Iguape/Litoral Sul. Além dos conflitos com os ambientalistas que alertam que as obras em andamento não obedeceram aos trâmites usuais, e têm sido aprovadas com laudos elaborados muito rapidamente em nome do saneamento da crise; conflitos com o Ministério Público e $\mathrm{ONG}$ acerca da transparência da situação de crise: haverá ou não rodízio ou racionamento? Eles já estão ocorrendo sob o título de diminuição noturna da pressão da água? Aliás, esta última é a única medida assumida pelo governo do estado. Veja-se o seguinte relato:

Morador do Mandaqui, zona norte da cidade de São Paulo, o estudante de jornalismo João Tiago Soares, 32, se queixa da falta de transparência praticada pela Sabesp. "Inacreditável. Até a Copa, tudo correu bem. Dias depois da final do campeonato, sem aviso prévio, o racionamento começou" - relata.

João afirma que no início faltava água por quatro horas durante a tarde e que depois foi faltando água cada vez mais tarde e por mais tempo. "Fechavam os 
reservatórios por volta das $22 \mathrm{~h}$, quando as pessoas se preparavam para dormir. Só abriam lá pelas 04h, quando estavam prestes a acordar", conta. João diz que sempre que ele ou algum vizinho telefonam para a Sabesp, a resposta é a mesma: estão realizando uma "adequação" no sistema hídrico (Dantas, 2015).

\section{As causas da crise hídrica}

O clima tem ritmo, mas também é variável, sujeito a excepcionalidades. Desta feita, a estiagem que atinge o Sudeste e o Centro-Oeste do país, entre 2014 e 2015, pode ser encarada como um fato previsível, comum ou como uma exceção, tudo depende da formação acadêmica ou/e técnica do relator (engenheiro, climatólogo, ambientalista, geógrafo, jornalista) ou do partido político ao qual ele pertence.

De fato, a estiagem existe e é uma das mais severas das últimas décadas, mas não se pode dizer que seja uma raridade na história e na geografia da região, e a causa primordial da crise. As causas também são, sem dúvida, o desmatamento ao redor dos reservatórios e a ocupação indevida de áreas de mananciais, até mesmo por pastagens.

Mas a crise mesmo é causada pela poluição dos recursos hídricos da bacia do Alto Tietê, limitando em muito o estoque de águas para o abastecimento doméstico. Há uma escassez relativa construída secularmente em São Paulo, uma crise lapidada, que vence em muito os argumentos sobre a estiagem e pelo fato de que a cidade está localizada numa cabeceira de rio, portanto pouco abundante em recursos hídricos.

\section{Crise nova ou crise antiga?}

Diríamos que é uma crise antiga, revestida de elementos novos, pois o histórico do abastecimento de água em São Paulo é repleto de crises. $\bigcirc$ processo de apropriação dos recursos hídricos da bacia do Alto Tietê revela que nem sempre se pensou na utilização dos recursos locais para o abastecimento doméstico, como se cogita nos dias atuais. Ao contrário disso, as águas locais foram mal faladas desde o tempo das bicas e chafarizes.

Quando as formas de abastecimento eram individuais, muito se utilizou dos afluentes esquerdos do córrego Anhangabaú e das bicas e fontes que brotavam em algumas vertentes. Contudo, havia queixas sobre a qualidade das águas obtidas. Quando iniciaram a implantação dos chafarizes - o primeiro foi em 1744 - as queixas continuaram.

Em 1791, segundo Branco et al. (1986, p. 353):

[...] o governador Lorena determinou ao Químico Bento Sanches d'Orta que procedesse a análise das fontes existentes na cidade usadas pela população. Vejamos alguns resultados então obtidos e encaminhados por Bernardo de Lorena à Câmara Municipal:

n. 3 - Água da Fonte do Gayo. É muitíssimo férrea e fria, ácida vitriólica, a base térrea calcária, de oca, com algumas partículas senicais, ainda que tênue e sumamente saturada de gás mefítico. Qualidades perniciosíssimas à economia animal, e bem capazes de produzir moléstias graves.

n. 4 - Água do rio Tamanduateí. É muito pouco férrea, ácida com sua base de 
terra argilosa e vegetal, o que compõe uma mistura lodosa pesada. Cheia de ar fixo e inflamável, de onde procede à má cor e mau gosto dessa água. $\bigcirc$ seu uso não seria muito pernicioso: mas, para branquear pano de linho ou algodão não é muito boa.

A par disso, havia poucas fontes para uma população crescente. Quem possuía recursos comprava água dos aguadeiros, mas a maioria ficava sujeita à má qualidade do líquido fornecido e à escassez relativa, sobretudo nos períodos de estiagem. Chafarizes insuficientes, danificados, com água ruim persistiram como forma de abastecimento de água até o final do século XIX.

Em 1828, registros municipais recriminavam a falta de água na cidade e descreviam a disputa pela água, quando "[...] os buscadores se engalfinhavam e muito pote de barro era quebrado [...]" (Yoshimoto et al., 1980, p. 18).

As águas do Tietê (nas proximidades da cidade) e principalmente as do Tamanduateí, dizia-se que eram poluídas há muito, desde o tempo da exploração de ouro e ferro, na área da capital e seus arredores: "[...] minas da Colina do Carmo, próximo ao Pátio do Colégio [...]" (Rocha, 1991, p. 44). Somados às escavações das várzeas, que pioravam o problema das enchentes, e ainda aos dejetos lançados nos rios, os metais pesados comprometiam a qualidade das águas. Assim, apesar do uso dos recursos locais para a lavagem de roupas, pesca e navegação havia uma resistência ao uso doméstico. A Lei n. 27, de 11 de maio de 1859, aprovou o uso dos mananciais da Serra da Cantareira para abastecimento da cidade.

Segundo o Relatório do Presidente da Província, Dr. Sebastião José Pereira, à Assembleia Legislativa Provincial, de 1876: "a população pedia com instância que se mandasse conduzir dos opulentos mananciais da Cantareira o elemento de saúde e de vida, que não podia ser fornecido pelos mesquinhos e imundos depósitos das cercanias da cidade".

Em 1875, São Paulo, com cerca de 35 mil habitantes, contava com vinte chafarizes. Nesse ano, quando da contratação da empresa privada Companhia Cantareira de Águas e Esgotos, houve grande divergência de opiniões, revelando os grupos de interesses envolvidos na questão, "uns defendiam a utilização dos mananciais da Cantareira, outros eram pelo aproveitamento da água de outras fontes" (Andrade, 1991, p. 50), mas predominou a busca de água a $14 \mathrm{~km}$ ao norte da cidade, nos mananciais da Cantareira. Bem verdade que se aduziu águas do Ipiranga e se tentou a perfuração de poços profundos às margens do Tamanduateí. Mas predominava a ideia de buscar mananciais distantes.

Quando a Light and Power Company, empresa canadense, chegou em São Paulo em 1899, encontrou pouca resistência na utilização dos recursos locais para o fornecimento de energia e transporte elétricos para a cidade. Muito ao contrário, pois finalmente alguém ia dar um uso efetivo para aquelas águas que causavam enchentes, doenças e mal odor. A iniciativa da empresa foi encarada como um avanço, um progresso para a cidade. Mesmo com a oposição de alguns membros da Câmara. 
A apropriação exclusivista e perniciosa que fez a Light da bacia do Alto Tietê é amplamente conhecida. Acordos com os governos federal e estadual levaram à criação da Barragem de Parnaiba, em 1901, a jusante da cidade; à formação da represa Guarapiranga, em 1908, na zona sul; à elaboração do Projeto Serra, que consistia na apropriação do canal do rio Pinheiros e de suas várzeas inundáveis, na criação da represa Billings e de um sistema de tubulação para - lançamento das águas do Planalto para a Baixada Santista, gerando energia nas usinas de Henry Bordem I e II (Figura 6).

\section{Figura 6 - Obras da Light no Alto Tietê}

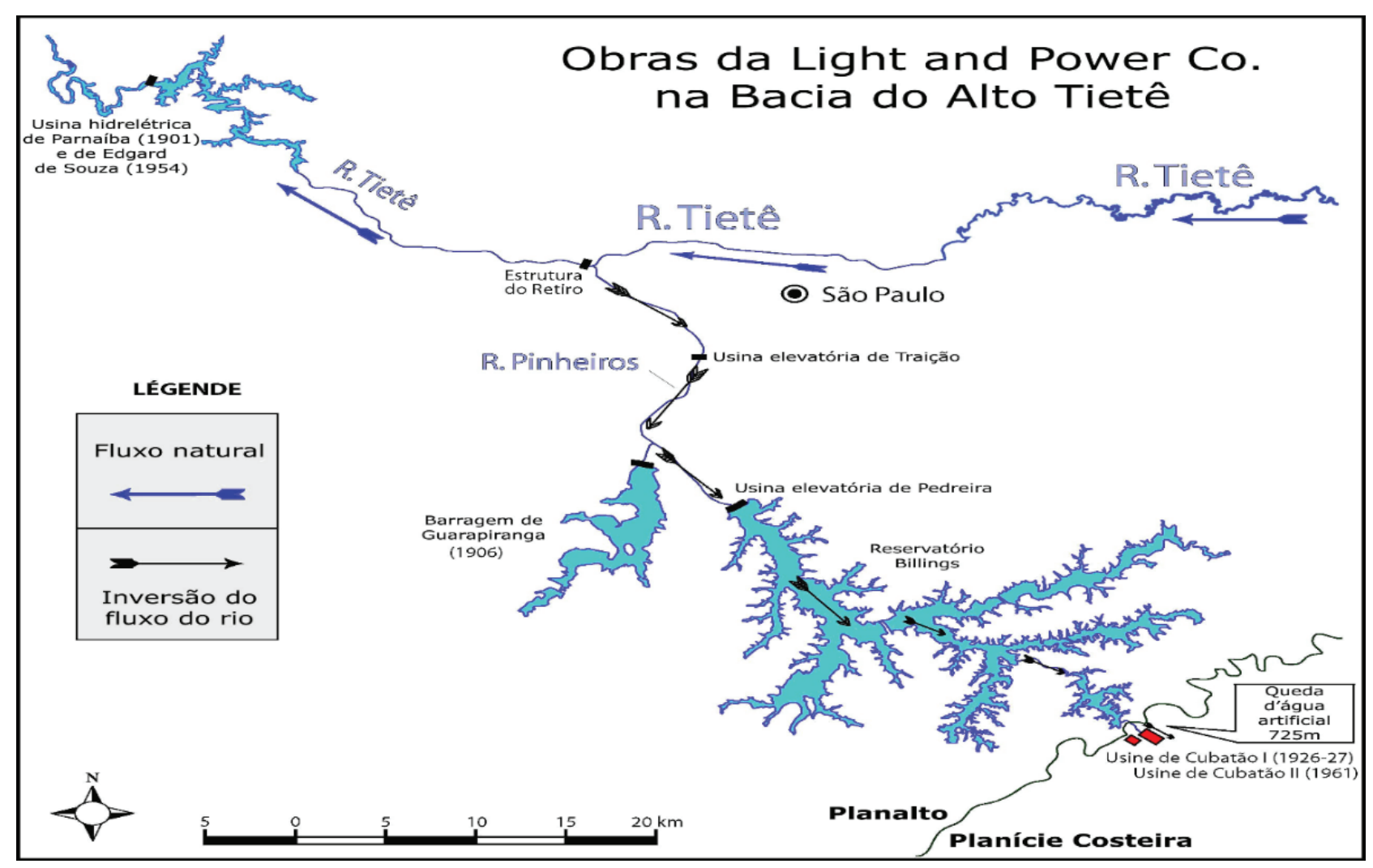

elaboração: Mateus Sampaio, 2008. reelaboração: Denis Cossia, 2010.

A partir de então, toda proposta de uso das águas da bacia do Alto Tietê que questionasse o sistema energético da empresa deixava de ser realizada. Mesmo assim, houve algumas medidas para o uso dos mananciais da bacia para abastecimento doméstico, por exemplo, durante a seca de 1903. Providências como essas, imediatistas, em períodos de exceção, eram comuns em São Paulo, o que levou à construção do Sistema Cabuçu-Barrocada (1905), na zona norte da cidade, por parte da RAE, abastecendo os reservatórios da Mooca e da Consolação, bem como a Caixa de Santana e daí atendendo os bairros de Santana, Luz, Brás e Bom Retiro.

Todas as medidas estruturais foram tomadas de emergência por parte do poder público estadual, por causa da estiagem. Isso levou, inclusive, a investigações sobre a captação de novos mananciais para a cidade. Euclides da Cunha, em 1903, elaborou um estudo sobre o aproveitamento do Rio Claro, a 80 km, leste da cidade, ainda na bacia do Alto Tietê. 
Em 1914, a RAE começou a adução no rio Cotia, distante $22 \mathrm{~km}$, a oeste da cidade, ainda na bacia do Alto Tietê. A adução deu origem aos atuais sistemas Alto e Baixo Cotia, concluídos em 1923, e que desatentavam para o sistema energético da Light; mas perceba-se a busca de águas cada vez mais distantes, relegando a segundo plano os mananciais constituídos pelos rios Tietê, Tamanduateí, Pinheiros, Aricanduva e outros.

Em 1913, Saturnino de Brito propôs a utilização do rio Tietê para tal fim, elaborando um Plano Geral de Abastecimento de Água para a cidade, no qual assim se manifestava:

[...] a favor da utilização do rio Tietê, manancial amplo e criticando obras de emergência se perpetuando, ou seja, a necessidade ininterrupta de obras novas de adução, atacando, também, os que defendiam a captação sistemática de águas de cabeceiras por se intimidarem ante a poluição dos rios e duvidarem do progresso tecnológicol de tratamento de água (São Paulo, 1985, p. 89-90).

No entanto, apesar da severa estiagem de 1923-1925, o uso desses grandes mananciais foi postergado e novas medidas emergenciais foram tomadas, com atuações do poder público sempre aquém das necessidades e, normalmente, sem o planejamento adequado. As ideias de Euclides foram retomadas, e deu-se início à construção do Sistema Rio Claro que - por interferências da Light, como a difamação dos mananciais locais para uso doméstico - só foi concluído em 1941. Nesse mesmo período, a Light começou o Projeto Serra (1925-1961), e como escreveu Catullo Branco (1975, p. 83): "o caso é que nunca mais se falou em represamento do Alto Tietê para saneamento da capital”.

Como tratado em outro texto (Custódio, 2012), o governo estadual obteve, por intermédio do decreto n. 4.487 de 9 de novembro de 1928, a permissão para retirar até o máximo de $4 \mathrm{~m}^{2} / \mathrm{s}$ de água da represa Guarapiranga, criada em 1906 pela Light. Captação que começou nos anos 1940, após compensações do governo do estado de São Paulo cedidas à empresa.

Na década de 1940, os sistemas que abasteciam a cidade eram: Cantareira, Cabuçu, Cotia, Santo Amaro (Guarapiranga) e Rio Claro, num total de 5,435 m³ $/ \mathrm{s}$, para uma população de cerca de 1.300 .000 habitantes, que convivia com a distribuição irregular de água e com crises sucessivas, sobretudo nas estiagens. Enquanto isso, as poluições doméstica e industrial iam inutilizando os mananciais locais para os vários usos possíveis: olarias, hortas, prática de esportes, piscicultura, lazer e recreação em geral. Dizia-se que a água do Tietê utilizada na irrigação de hortaliças queimava as plantas (Rocha, 1991, p. 45).

Em 1942, ano da reversão do canal do Pinheiros, foi elaborado pela RAE o Primeiro Plano Geral de Abastecimento de São Paulo, com previsão de implantação para 30 anos, no qual constou a proposta de adução de $15 \mathrm{~m}^{3} / \mathrm{s}$ no rio Paraiba do Sul. O Plano, contudo, encontrou uma legislação falha, um setor energético fortemente instalado e um setor de saneamento politicamente frágil. Em 1948 foram ampliadas as obras de adução do Guarapiranga, que receberam novo impulso em 1953. No ano seguinte, a RAE foi transformada em Departamento de Águas e Esgotos (DAE), para tentar sanar as falhas na estrutura organizativa da Repartição e as deficiências na distribuição de água. O DAE possuía autonomia para prestar serviços de água e esgoto para São Paulo, Santo André, São Bernardo, São Caetano do Sul e Guarulhos.

1 A desinfecção com cloro passou a ser obrigatória em 1925, com a reformulação do Serviço Sanitário do Estado de São Paulo. 
Cumpre salientar que o DAE passou a dar importância à questão da poluição da macrodrenagem - por exemplo, procurando controlar a poluição industrial -, mas foram medidas tímidas em face da problemática situação dos mananciais urbanos.

Em 1951, criou-se o Daee, com a finalidade de pensar o aproveitamento regional e múltiplo dos recursos hídricos. Um órgão importante, com papel de destaque no equacionamento das questões das águas da bacia do Alto Tietê, por exemplo, detendo alguns reservatórios e elaborando estudos. Em 1958, estabeleceram-se os padrões de potabilidade da água para o estado de São Paulo, foram ampliadas as captações na Guarapiranga e teve início a adução do braço Rio Grande, da represa Billings; ações realizadas mediante desgastantes negociações com a Light. Em 1963, por conta da poluição na represa, foi construída uma barragem isolando o referido braço.

Importante entre as ações iniciais do Daee foi a contratação, em 1964, do Plano Hibrace $^{2}$ para a realização de um Plano Diretor de Obras e Aproveitamento Múltiplo das Águas do Alto Tietê e Cubatão, com horizonte para o ano 2000. Estimava-se a necessidade de 72 $\mathrm{m}^{3}$ /s de água para uma população de 19 milhões de habitantes. Os sistemas considerados para tanto foram: o Sistema Tietê (atual Alto Tietê), Sistema Guarapiranga, Sistema Juqueri (atual Cantareira), Sistema Cotia, Sistema Baixada Santista e o Sistema Billings. Neste último caso, havia a proposição de uso do corpo central do reservatório a partir de 1990. No geral, o Plano pouco questionou o sistema Light e propunha a reversão de um conjunto de cursos d'água. Foi a primeira vez que se cogitou o uso do corpo central da Billings para abastecimento doméstico. Ainda sobre o Plano:

Plano Hibrace, que começou a ser implantado a partir de 1964, contemplava, entre outros, a construção de barragens regularizadoras nas cabeceiras do Tietê e afluentes, a retificação e/ou canalização, limpeza e desassoreamento dos rios Tietê, Tamanduateí, Pinheiros, e de seus principais afluentes, como medidas acessórias necessárias ao controle de cheias, para evitar as inundações que a cada ano se tornavam mais frequentes na região da Capital e municípios vizinhos, especialmente na região do ABC. $\bigcirc$ abastecimento de água da região metropolitana de São Paulo e o destino final dos esgotos dessa região eram outros importantes objetivos do Plano. Só em 1993 concluiu-se pela necessidade da revisão, atualização e ampliação do escopo do Plano Hibrace, o que foi efetivado mediante a contratação do consórcio Hidroplan (Coplasa-Etep-Figueiredo Ferraz-Hidroconsult-Maubertec) para a elaboração do Plano Integrado de Aproveitamento e Controle dos Recursos Hídricos das Bacias do Alto Tietê, Piracicaba e Baixada Santista (Ortiz; Silva, 1998).

Como podemos constatar pela crise atual, o Plano e sua revisão não tiveram o alcance esperado, mesmo com a população tendo ficado abaixo dos 19 milhões estimados para o ano 2000. Ainda nos dias atuais, mesmo sem estiagem, a Sabesp tem dificuldades para alcançar os $74,2 \mathrm{~m}^{3} / \mathrm{s}$ que produz.

2 Formado pelas consultorias Hidroservice, Brasconsult e Planidro. 
Nossa intenção foi a de elaborar uma seletiva cronologia do abastecimento de água em São Paulo, e assim apenas expor como os sistemas atuais foram instituídos, indicar que a crise que ora passamos era previsível, bem como a atuação do poder público estadual reiteradamente assombrado pelas estiagens e tomando medidas emergenciais, aquém das demandas e se utilizando de mananciais cada vez mais distantes, com poucas exceções. Desta feita, o histórico aqui expresso cumpriu a finalidade, mesmo com lacunas que os profissionais do setor de engenharia hidráulica e sanitária possam considerar imperdoáveis.

O que ora passamos é uma crise antiga com nova roupagem.

\section{A Sabesp}

A Sabesp nasceu no bojo do Plano Nacional de Saneamento Básico (Planasa), na década de 1970. Nasceu como uma empresa de economia mista.

A proposta da criação de empresas de saneamento de economia mista surgiu na década de 1950, com os princípios de que toda água consumida deveria ser paga e de que era preciso criar tarifas sociais para que os mais pobres tivessem acesso à água para higiene e alimentação (Rezende; Heller, 2008, p. 236). Reforçando a proposta:

O Banco Interamericano de Desenvolvimento (BID), a partir de 1960, também estimulou a formação das empresas de economia mista por meio de imposições contratuais de financiamento, exigindo a descrição das responsabilidades, autonomia administrativa, autoridade para impor a tarifação, arrecadação e legislação por parte das contratantes (Rezende; Heller, 2008, p. 238).

A criação do Banco Nacional de Habitação (BNH), em 1967, durante o período militar, deu novo impulso à proposta, financiando as empresas com o Fundo de Garantida por Tempo de Serviço (FGTS), mais verbas provenientes do BID.

Cada vez mais os recursos vinham condicionados à "transferência da concessão dos serviços de saneamento às empresas estaduais de economia mista" (Rezende; Heller, 2008, p. 238).

Assim, no estado de São Paulo, em 1968, foi criada a Companhia Metropolitana de Águas de São Paulo (Comasp), uma empresa de cunho regional fornecendo água por atacado aos 38 municípios, do que seria em 1973, a RMSP. Foram criadas também a Companhia de Saneamento da Baixada Santista (SBS), a Companhia Metropolitana de Saneamento de São Paulo (Sanesp), a Superintendência de Água e Esgotos da Capital de São Paulo (Saec), em 1970; e a Companhia Regional de Água e Esgotos do Vale do Ribeira (Sanevale), em 1972.

A formação da Sabesp, em 1973, veio incorporar progressivamente todas essas empresas. Atingiu-se o objetivo que vinha sendo projetado desde os anos 1950, e ratificado no Planasa, o de atuar em âmbito estadual passando por cima da prerrogativa constitucional dos municípios de serem os titulares na prestação de serviços de saneamento básico.

A Sabesp executou importantes medidas obras estruturais e programas não estruturais nessas décadas de atuação, tais como a implantação do Sistema Adutor Metropolitano (SAM), a proposição de um Programa de Abastecimento de Água para a RMSP para o período 1975-1978, a contratação de um Plano Diretor de Águas, em 1976, que propunha como mananciais os seguintes sistemas: Cantareira, Rio Grande, Cotia, Alto Tietê e Guarapiranga. 
Este último receberia um adendo de águas provenientes do Capivari-Monos, do Alto Juquiá e da Billings. Veja-se a intenção de uso dos mananciais do Juquiá. Concluiu o Sistema Cantareira e construção do Sistema Alto Tietê, com os respectivos reservatórios, entre muitas outras intervenções. Contudo, aquém das necessidades metropolitanas.

Vale voltarmos ao Planasa. $\bigcirc$ problema dele, que refletiu na atuação da Sabesp, foi a prioridade dada à expansão do abastecimento de água e, em segundo plano, a implantação da rede de esgoto. Aliás, o Planasa deixou de contemplar as outras duas dimensões do saneamento, quais sejam: a drenagem e a coleta e deposição de resíduos sólidos. Era um plano de água e esgoto. $\bigcirc$ resultado foi positivo num primeiro momento: expansão da rede de água, e diminuição significativa da mortalidade infantil em São Paulo, de 95/1.000 em 1973, para 53/1.000 em 1981 (São Paulo, 1981). Contudo, toda a água que entra num sistema se torna esgoto que precisa ser tratado, o que não foi realizado, ou o foi de modo muito incipiente, contribuindo para a poluição dos recursos hídricos da bacia do Alto Tietê, também pelo fato de a Sabesp ter evitado intervenções que questionassem o domínio energético da Light and Power Company na bacia. Tal poluição, que no extremo gerava energia para o parque industrial da metrópole, agravou a escassez de água na bacia local.

Houve propostas de tratamento de esgoto como o Plano Greeley and Hansen, elaborado por uma empresa estadunidense em 1953, o Plano Hibrace, de 1964, o Plano Metropolitano de Desenvolvimento Integrado (PMDI), de 1971, o Programa de Tratamento de Esgotos para a Grande São Paulo (Sanegran), de 1976, e o, em andamento, Projeto de Despoluição do Rio Tietê, de 1991. Foram estudos importantes que propuseram várias medidas, como até o lançamento dos esgotos da metrópole no oceano, mas vingou a progressiva construção de grandes estações de tratamento de esgotos, como a de Barueri, por exemplo.

Nos anos 1990, começou a pressão para a privatização de várias empresas públicas, preceito dos anos neoliberais que se afirmavam, inclusive as companhias estaduais de saneamento básico. Houve constrangimentos externos no sentido de o poder público ser desaconselhado a prestar auxílio a essas empresas que, sob pressão, como é o caso da Sabesp, abriu o capital na bolsa de valores e começou a negociar água como commodities.

Sua atuação, apesar da participação majoritária das ações serem do governo do estado, passou a ser caracterizada cada vez mais como a de uma empresa privada, na busca de lucros. Nesse sentido, a Sabesp se tornou uma das 25 maiores empresas de saneamento do mundo. $\bigcirc$ seu negócio é fornecer água, assim, quanto maior o fornecimento, melhores os rendimentos, mesmo que isso signifique a superutilização dos mananciais.

No processo de expansão dos negócios, a empresa vem desde 2002 firmando os contratos ditos de "demanda firme": são 537 contratos com estabelecimentos industriais e comerciais.

Trata-se de "fidelizar" o cliente grande consumidor de água, que antes usava minimamente a Sabesp, em razão da intermitência do abastecimento e do alto custo. A partir de 2010, os contratos passaram a valer para os que consomem acima de 500 m³/mês. Segundo Arteta et al. (2015):

programa prevê um consumo mínimo de água. Se a empresa consumir menos, pagará o valor completo de todo jeito. Se ultrapassar a quantidade acordada, paga a diferença. Ou seja, a empresa é penalizada se economizar, e instada a usar mais água, já que pagará de qualquer forma. Outro problema nesse tipo de contrato é 
que a Sabesp exige exclusividade de fornecimento, abandonando fontes alternativas de água como poços artesianos e caminhões pipa. A Sabesp finalmente reviu essa obrigação de consumo mínimo em março do ano passado, depois do agravamento da crise hídrica. Mas os descontos previstos pelos contratos de demanda firme continuam a vigorar.

Uma característica desse programa de "fidelização" é que ele segue a lógica da venda a atacado: quanto maior o consumo médio de água da empresa, a tarifa é mais baixa, ao contrário do que a Sabesp exige dos usuários residenciais, que quanto mais usam, mais pagam. Os descontos na conta são generosos, chegando a 40\% do valor [...].

A polêmica se instalou porque os contratos de demanda firme continuam a vigorar em tempos de escassez de água. Continuaram a ser fechados mesmo durante a crise em andamento no ano de 2014 e a empresa se recusou a divulgar a lista com os nomes dos grandes consumidores, e quando o fez, excluiu muitas informações. No geral são clubes, condomínios, bancos, supermercados e indústrias automobilísticas. ONG, Ministério Público, mídia e população questionam o posicionamento da empresa e cobram medidas do governo do estado de São Paulo, cuja administração pelo mesmo partido político, reitere-se, perdura há 20 anos, configurando uma situação de incompetência de gestão e planejamento ao longo do tempo.

Como medidas para enfrentar a crise, obras emergenciais são anunciadas, causando novas polêmicas porque envolvem bacias vizinhas - Paraiba do Sul e Vale do Ribeira do Iguape/ Litoral Sul - com laudos ambientais questionados por $\mathrm{ONG}$ e Ministério Público.

Anuncia-se a construção do Sistema São Lourenço (Figura 7), com previsão para outubro de 2017. Trata-se de uma Parceria Público Privada (PPP) entre o governo do estado e as construtoras Andrade Gutierrez e Camargo Corrêa (Consórcio São Lourenço), com 25 anos de operação. Objetiva-se a produção de $4,7 \mathrm{~m}^{3} / \mathrm{s}$ a $6 \mathrm{~m}^{3} / \mathrm{s}$, captados na Cachoeira do França, Ibiúna, no Alto Juquiá que já pertence à UGRH do Ribeira do Iguape/Litoral Sul, para o atendimento de 1,5 milhão de pessoas. É um sistema que tem de vencer 700 metros de desnível em 83 quilômetros de adutoras, com tratamento numa ETA em Vargem Grande Paulista.

\section{Figura 7 - Sistema São Lourenço}

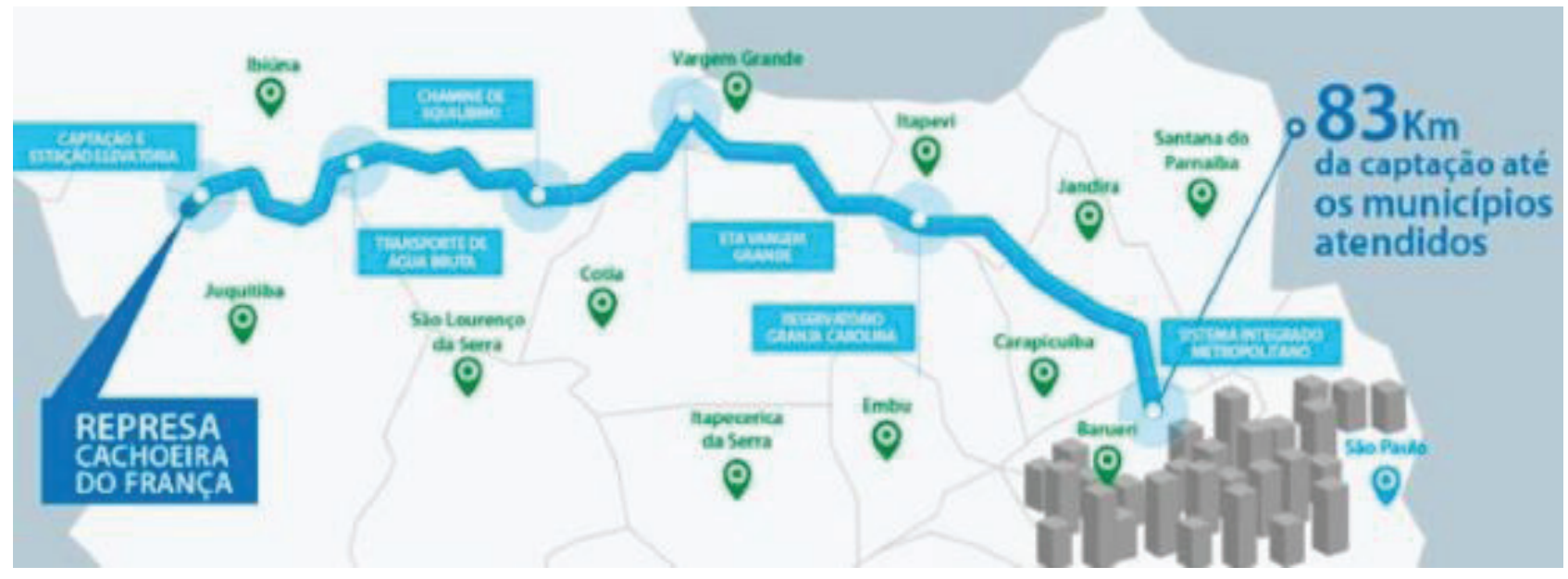

fonte: Louzas (2014). 
As consequências ambientais, políticas e para a população do Vale, resultantes dessa reversão, ainda são imprevisíveis, pois entre os anos 1950 e 1980, mananciais do Vale do Ribeira foram destinados à produção de energia elétrica para a Companhia Brasileira de Alumínio (CBA), do Grupo Votorantim e ainda pouco se sabe se haverá conflitos. Do ponto de vista da quantidade de água disponível - os opulentos mananciais suportam captação de 60 $\mathrm{m}^{3} / \mathrm{s}$ - haveria a possiblidade de usos múltiplos sem problemas. Porém, novamente se utiliza mananciais distantes.

Outra medida anunciada, e todas são no sentido de diminuir a dependência do Sistema Cantareira, que seria o mais afetado pela estiagem, é a interligação Rio Grande-Alto Tietê, com início em 2015, para a produção de $4 \mathrm{~m}^{3}$ /s, com desnível de 80 metros e 22 quilômetros de adutoras. A proposta é de transferência das águas da Billings para o Sistema Rio Grande, que atende a região do $\mathrm{ABC}$, e daí para Alto Tietê (Figura 8).

\section{Figura 8 - Interligação Rio Grande e Alto Tietê}

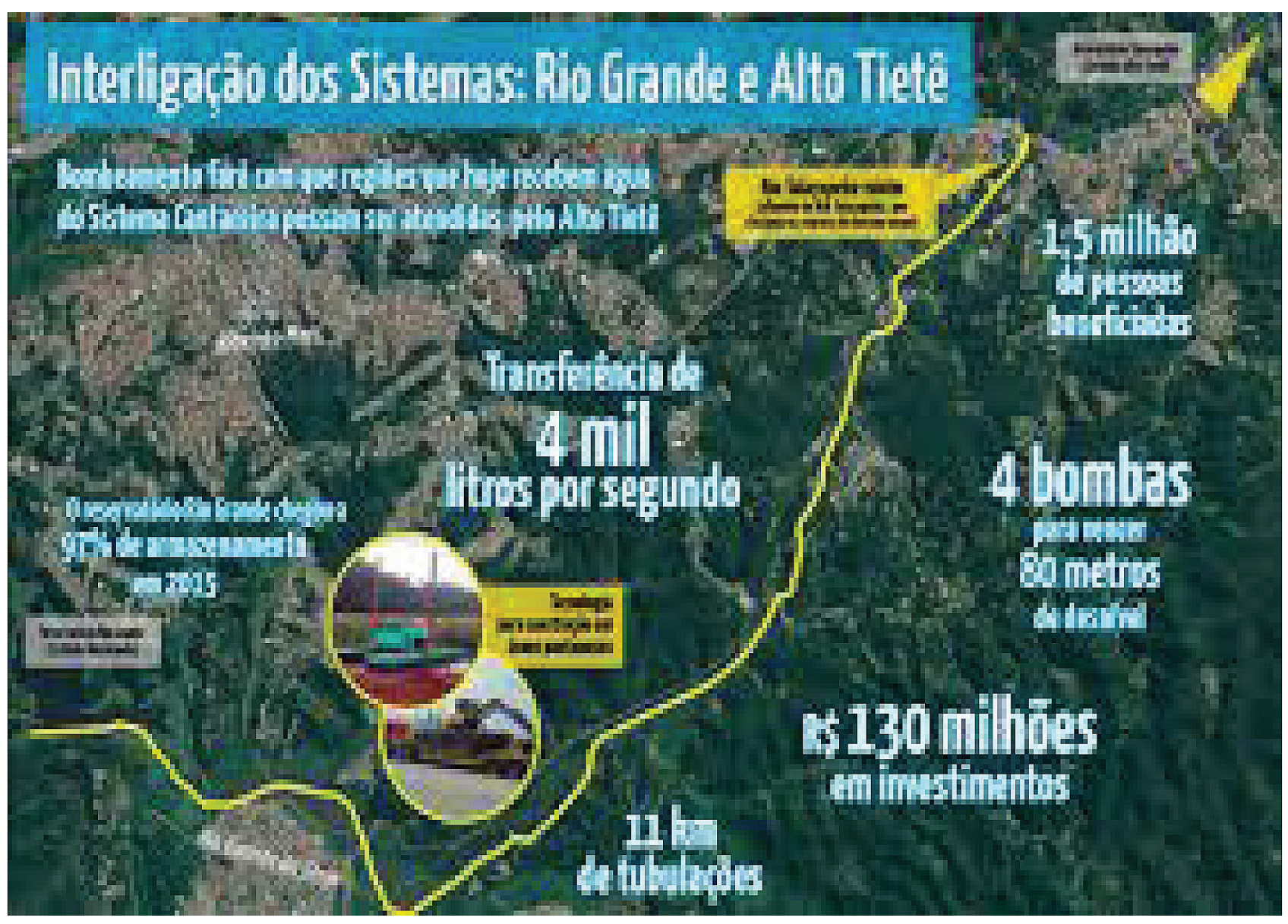

fonte: SIGRH (2015).

Outra interligação é a da bacia do Alto Tietê com a bacia do Paraiba do Sul (Figura 9), pela interligação do rio Jaguari (bacia do Paraiba do Sul) com o reservatório Atibainha (do Sistema Cantareira), para a produção de $5,13 \mathrm{~m}^{3} / \mathrm{s}$ a $8,5 \mathrm{~m}^{3} / \mathrm{s}$. 


\section{Figura 9 - Interligação Atibainha-Jaguari}

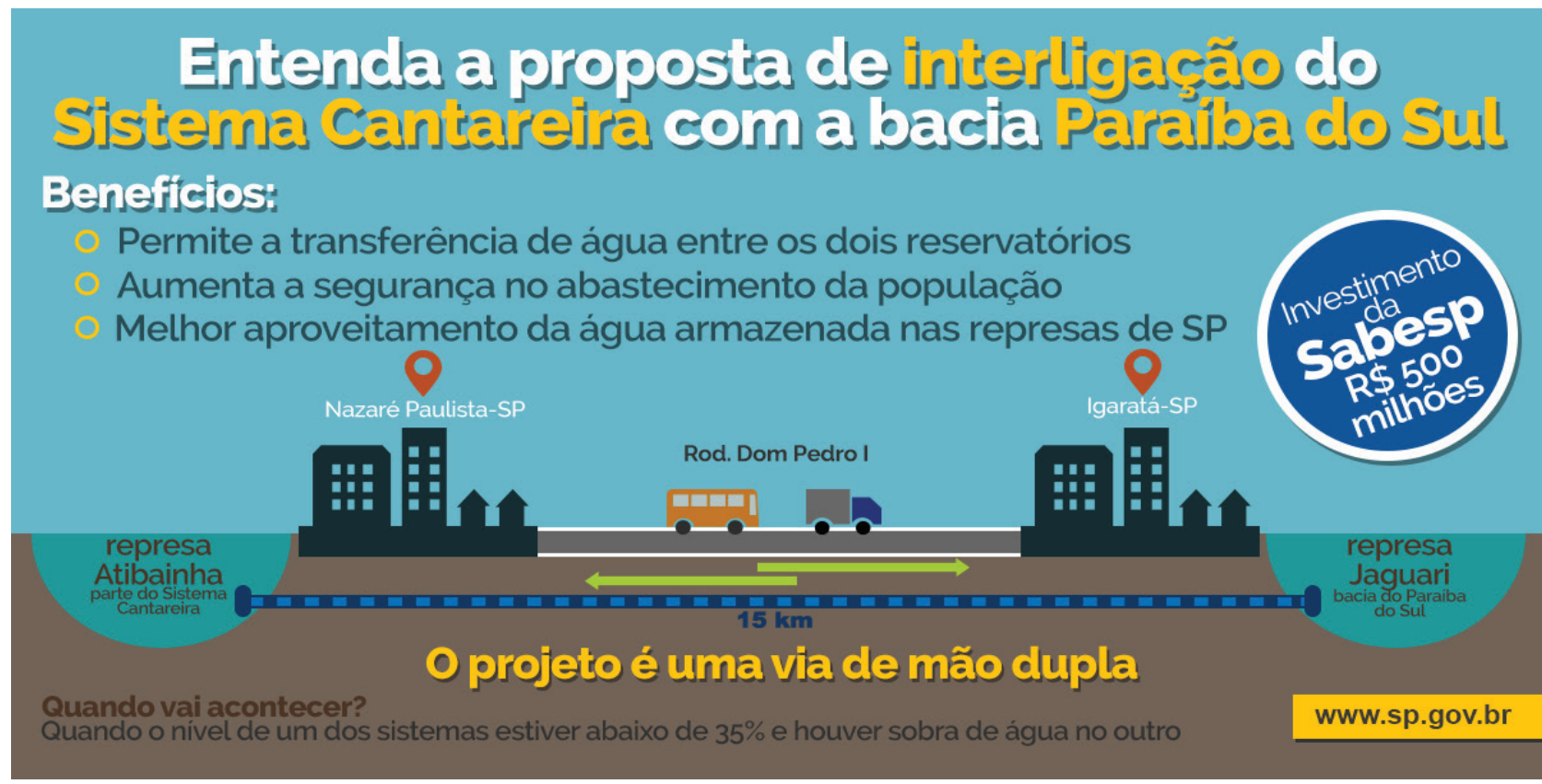

fonte: SP vai [...] (2014).

Esta última interligação tem causado conflitos entre os municípios do Vale do Paraíba, que exigem compensações pelo fornecimento de água entre os governos estaduais de São Paulo e do Rio de Janeiro, porque as águas que abastecem o Grande Rio provêm de mananciais do Vale do Paraiba. A polêmica exigiu a interferência da Agência Nacional de Águas (ANA), pelo fato de a questão envolver duas bacias.

Outras medidas polêmicas foram tomadas pelo governo paulista, via Sabesp, como a concessão de descontos para os usuários que reduzissem o consumo (mas e os contratos de demanda firme? $\bigcirc$ mesmo seria válido para eles?) e o uso do volume morto, a chamada "reserva técnica" do Cantareira (não estaria levando à exaustão do Sistema?). A par disso, a sociedade civil muito tem cobrado transparência na gestão da crise por parte do governo: não será a hora de assumir a necessidade de um racionamento? Ele já não está ocorrendo em alguns bairros da metrópole de forma dissimulada? Afinal, como funciona mesmo a Sabesp?

Como também houve estiagens nos anos 1980 e 1990, a ideia de se usarem os mananciais locais da macrodrenagem - Tietê, Pinheiros, Tamanduateí, Billings - veio ganhando corpo. ${ }^{3}$ Inclusive, nessas mesmas décadas, vem emergindo mundialmente um princípio de valorização dos rios urbanos e seus usos múltiplos. No Brasil também. Desta feita, é preciso registrar que é algo recente a consciência e a unanimidade de que perdemos nossos rios e córregos para a poluição e para a produção exclusiva de energia elétrica e de que temos de recuperá-los - ao menos alguns deles, como o da represa Billings ${ }^{4}$ - para o abastecimento doméstico.

3 É fundamental lembrar que a Lei de Proteção aos Mananciais da bacia do Alto Tietê é de 1975/76, e a mais recente, de 1997.

4 A questão é tecnicamente complexa, pois há muito lodo poluído no fundo do corpo central do reservatório. Trata-se de considerável passivo ambiental. 
Em 2013, elaborou-se o Plano Diretor de Aproveitamento dos Recursos Hídricos para a Macrometrópole Paulista, ${ }^{5}$ com propostas para o abastecimento de quatro regiões metropolitanas e três principais aglomerações urbanas, com horizonte para 2035. Esse plano considerou a alta vulnerabilidade da região a eventos críticos de escassez e a necessidade de soluções integradas visando o uso múltiplo das águas e ainda inclui a renovação do termo de outorga do Sistema Cantareira. Mas só o futuro dirá se será implementado.

\section{Considerações finais}

Percebe-se que um conjunto de fatores antigos compõe o quadro da atual crise hídrica da RMSP/do Alto Tietê. É mais uma adversidade no histórico de adversidades da escassez de água em São Paulo. Uma crise de gestão e planejamento, devido ao tratamento emergencial e paliativo que historicamente o poder público - sobretudo o estadual - tem dado à questão da apropriação das águas da bacia do Alto Tietê, que gerou relativa escassez e muito cedo levou a se cogitar o uso de mananciais cada vez mais distantes para abastecer a cidade, relegando o tratamento do esgoto e da poluição da bacia.

$\bigcirc$ equacionamento da questão passará, para além dos ditames técnicos, por intenso processo de negociação e governança das águas (Campos, 2009).

\section{Referências}

ANA. AGÊNCIA NACIONAL DE ÁGUAS. Sistema Cantareira, Brasilia, DF, 7 out. 2015. Disponível em: <http://www2.ana.gov.br/Paginas/servicos/outorgaefiscalizacao/sistemacantareira.aspx>. Acesso em: 10 dez. 2015

ANDRADE, M. M. Bairros além Tamanduateí: o imigrante e a fábrica no Brás, Mooca e Belenzinho. Tese (Doutorado em Geografia Humana) - Faculdade de Filosofia, Letras e Ciências Humanas, Universidade de São Paulo, São Paulo, 1991.

ARTETA, C. et al. Finalmente, os contratos de demanda firme. Pública, São Paulo, 22 maio 2015. Disponível em: <em http://apublica.org/2015/05/finalmente-os-contratos-de-demanda-firme/>. Acesso em: 22 jul. 2015.

BRANCO, C. Energia elétrica e capital estrangeiro no Brasil. São Paulo: Alfa-Ômega, 1975.

BRANCO, S. M. et al. Episódios pitorescos selecionados da história do saneamento em São Paulo. Revista DAE, v. 46, n. 147, dez. 1986.

BRASIL. Censo demográfico de 2010. Rio de Janeiro: IBGE, 2012.

CAMPOS, V. N. O. Estruturação e implantação da gestão compartilhada das águas: o Comitê de Bacia Hidrográfica do Alto Tietê. In: JACOBI, P. R. (Org.) Atores e processos na governança da água no estado de São Paulo. São Paulo: Annablume, 2009.

5 O plano é formulado no contexto de atuação de um novo órgão criado em 2007, a Agência Reguladora de Saneamento e Energia do Estado de São Paulo (Arsesp), cuja função, no setor de saneamento, é regular e fiscalizar os contratos com os municípios paulistas. A partir de 2010, a agência passou a atuar também na capital paulista. 
CUSTÓDIO, V. Escassez de água e inundações na Região Metropolitana de São Paulo. São Paulo: Humanitas/Fapesp, 2012.

DAEe. DePARTAMENTO de ÁGUAS e eneRGiA ElÉTRICA. Portaria Daee N.

1.213, de 6 de agosto de 2004. São Paulo: Disponível em: < http://www.agenciapcj.org.br/docs/gestao/portaria-daee-1213. pdf>. Acesso em: 15 ago. 2015. . Plano de Bacia do Alto Tietê, São Paulo: Fusp, 2002.

DANTAS, L. Água: crise e colapso em São Paulo. Revista Greenpeace, n. 3, 2015. Disponível em: <revistagreenpeace.org/segunda-materia/agua-crise-e-colapso-em-sao-paulo/>. Acesso em: 13 jul. 2015.

IBGE. INSTITUTO BRASILEIRO DE GEOGRAFIA E ESTASTÍSTICA. Produto interno bruto dos municípios 2004-2008. Rio de Janeiro, 2010. (Contas nacionais, n. 33.) Disponível em: <http://www.ibge.gov.br/home/estatistica/economia/pibmunicipios/2004_2008/pibmunic2004_2008.pdf>. Acesso em: 14 set. 2015.

LIDERANÇA DO PT NA ALESP. A crise da água, abr. 2014. Disponível em: <http:// slideplayer.com.br/slide/1746346/>. Acesso em: 14 set. 2015.

LOUZAS, R. Começam as obras do Sistema Produtor São Lourenço, em São Paulo. Pini Web, local, 14 abr. 2014. Infraestrutura urbana. Disponível em: <http://infraestruturaurbana.pini.com.br/solucoes-tecnicas/Saneamento/comecam-as-obras-do-sistema-produtor-sao-lourenco-em-sao-310784-1.aspx>. Acesso em: 12 dez. 2015.

ORTIZ, J. B.; SILVA, A. P. Um pouco do passado, presente e futuro. Revista Água e Energia, São Paulo, out. 1998. Disponível em: <http://www.daee.sp.gov.br/acervoepesquisa/relatorios/revista/raee9810/hist.html>. Acesso em: 22 jul. 2015.

PASCHOALOTTI, E. L.; MARTINI NETO, W. Sistema Cantareira: o desafio para atender regiões hidrográficas diferentes com uma disponibilidade hídrica limitada. Águas do Brasil, Birigui, n. 6, [s.d.]. Disponível em: <http://aguasdobrasil.org/edicao-06/sistema-cantareira.html >. Acesso em: 13 jul. 2015.

RELATÓRIO DO PRESIDENTE DA PROVÍNCIA. Dr. Sebastião José Pereira à Assembleia Legislativa Provincial, 1876, p. 4. Disponível em: <http://brazil.crl.edu/bsd/bsd/1017/ index.html>. Acesso em: 14 set. 2015.

REZENDE, S. C.; HELLER, L. O saneamento no Brasil: políticas e interfaces. Belo Horizonte: Ed. UFMG, 2008.

ROCHA, A. Do lendário Anhembi ao poluído Tietê. São Paulo: Edusp, 1991.

SÃO PAULO (Estado). Secretaria de Estado de Energia, Recursos Hídricos e Saneamento. Departamento de Águas e Energia Elétrica. Portaria n. 1.213, de 6 de agosto de 2004. Disponível em: <http://www.agenciapcj.org.br/docs/gestao/portaria-daee-1213.pdf>. Acesso em: 7 ago. 2015.

Estudos socioeconômicos, políticos e biogeográficos para avaliação de impactos ambientais - v. 1. São Paulo: Cetesb, 1985. 
Relatório da diretoria. São Paulo: Sabesp, 1981.

SIGRH. SISTEMA INTEGRADO DE GERENCIAMENTO DE RECURSOS HÍDRICOS DO ESTADO DE SÃO PAULO. Governo inicia obras de interligação entre sistemas, São Paulo, 5 maio 2015. Disponível em: < http://www.sigrh.sp.gov. br/pageitems/450/news/172>. Acesso em: 14 set. 2015.

SP VAI INTEGRAR SISTEMA CANTAREIRA E BACIA DO PARAÍBA DO SUL. Portal do Governo do Estado de São Paulo, São Paulo, 19 mar. 2014. Disponível em: $<$ http://www.saopaulo.sp.gov.br/spnoticias/lenoticia.php?id=236229>. Acesso em: 14 set. 2015.

YOSHIMOTO, P. M. et al. RMSP: evolução e aproveitamento das águas. Revista SPAM, São Paulo, v. I, n. 10, dez. 1980. 